\title{
TRACING THE DECLINE OF YUGOSLAV IDENTITY: A CASE FOR 'INVISIBLE' ETHNIC CLEANSING
}

\section{ABSTRACT}

This essay explores the concept of invisible ethnic cleansing by examining the remaining group of self-identifying Yugoslavs who continue to identify themselves as such despite the break-up of Yugoslavia, the country that shaped and constituted the focal point of their identity. The analysis argues that the lack of recognition of the Yugoslav identity during the country's disintegration as well as afterwards in the individual republics befitted the new nationalistic and distinctly anti-Yugoslav narratives adopted by individual post-Yugoslav republics. The sheer existence and acknowledgment of the Yugoslav identity could therefore disprove the new nationalistic tenets. The essay begins by setting up an analytical framework for the study of invisible ethnic cleansing and Yugoslav identity by examining the concepts of ethnic cleansing, nationalism, group destruction and ethnicity. It goes on to establish the historical background for Yugoslavia's break up and looks at Yugoslavia's 'nationalities policy', the break up itself and the role of the West and the Western media. Finally, the study identifies the hegemonic power of current nation-states reflected in the media, education and government-sponsored intellectual efforts, as those that control the image of the past can erase from it the memory of the disappeared states and the identities connected to them. The bulk of the analysis and the conclusions drawn were based on personal memoires and accounts of self-identifying Yugoslavs in order to preserve the memories of marginalized and forgotten groups as well as to stress the importance of counter-memory, which can challenge the narrative promoted by dominant groups and oppressive states. Moreover, the novel concept of invisible ethnic

HANA SREBOTNJAK

University of St Andrews, St. Andrews, United Kingdom

E-mail: hana.srebotnjak92@gmail.com This work was supported by the author's own resources. No competing interests have been declared.

This is an Open Access article distributed under the terms of the Creative Commons Attribution 3.0 PL License (creativecommons.org/licenses/by/3.0/pl/), which permits redistribution, commercial and non-commercial, provided that the article is properly cited. (C) The Author(s) 2016.

Publisher: Institute of Slavic Studies, Polish Academy of Sciences [Wydawca: Instytut Slawistyki PAN] 
cleansing introduced will allow scholars to examine the loss of supranational identities, which accompany the dissolutions of multinational states.

Key words: Post-Yugoslavia; invisible ethnic cleansing; identity loss; nationalism; politics of memory; historical amnesia; Yugonostalgia

\section{JAK GINIE TOŻSAMOŚĆ JUGOSLOWIAŃSKA: PRZYPADEK "NIEWIDZIALNEJ” CZYSTKI ETNICZNEJ}

\section{Streszczenie}

Esej podejmuje kwestię niewidzialnej czystki etnicznej, w oparciu o badania nad grupą osób samoidentyfikujących się jako Jugosłowianie, które nadal tak właśnie siebie identyfikują pomimo rozpadu Jugoslawii -- kraju, który uksztaltował ich tożsamość i stworzył dla niej punkt odniesienia. Analiza dowodzi, że nieuznawanie tożsamości jugosłowiańskiej w okresie dezintegracji Jugosławii i po rozpadzie tego kraju w poszczególnych republikach przyniosło nowe nacjonalistyczne i wyraźnie antyjugosłowiańskie narracje przyjęte przez poszczególne republiki postjugosłowiańskie. Samo istnienie i uznanie tożsamości jugosłowiańskiej mogłoby zatem podważać nowo wyznaczone nacjonalistyczne cele. Autorka najpierw wyznacza ramy analitycznego podejścia do niewidzialnej czystki etnicznej i tożsamości jugosłowiańskiej poprzez analizę takich pojęć, jak: czystka etniczna, nacjonalizm, destrukcja grupy i etniczność. Następnie przechodzi do omówienia historycznego tła rozpadu Jugosławii i "polityki narodowościowej” Jugosławii, samego rozpadu kraju oraz roli, jaką odegrał Zachód i media zachodnie. Ostatnia część opracowania zawiera ustalenia odnoszące się do hegemonii władzy współczesnych państw narodowych, która odzwierciedla się w mediach, szkolnictwie i wspieranych przez rząd wysiłkach intelektualnych, ci bowiem którzy zawiadują obrazem przeszłości mogą z niej wymazać pamięć o państwach, które przestały istnieć i o związanych z nimi tożsamościach. Analiza i wnioski w zasadniczej części opierają się na wspomnieniach osobistych i relacjach samoidentyfikujących się Jugosłowian, którzy dążą do zachowania pamięci o marginalizowanych i zapomnianych grupach, jak też podkreślenia wagi kontrpamięci, mogącej stać się wyzwaniem dla narracji promowanej przez grupy dominujące i opresyjne państwa. Ponadto, wprowadzona tu nowa koncepcja niewidzialnej czystki etnicznej pozwoli badaczom zgłębiać utratę tożsamości ponadnarodowych, która towarzyszy rozpadowi państw wielonarodowościowych.

Słowa kluczowe: Jugosławia; niewidoczna czystka etniczna; utrata tożsamości; nacjonalizm; polityka pamięci; amnezja historyczna; Jugonastalgia

\footnotetext{
1
} he term ethnic cleansing, etničko čiščenje in Serbo-Croatian, which originated in and was first used by the paramilitaries in former Yugoslavia to describe their political agenda, entered the Western discourse in 1992 with the break up of Second Yugoslavia (end of Second War - 1991) and the extreme violence that accompanied the secession of its individual states. The close of the $20^{\text {th }}$ century saw in the territory of former Yugoslavia an unforeseen level of brutality, which particularly distressed Europe after a period of relative peace since World War II. The instances of genocide in Bosnia, the exceptional human losses in all of the Republics, and the ruthless sexual violence encapsulate the tragedy that was the Yugoslav war. Consequently, the bulk of the literature written on Yugoslavia's end thus far revolved around forms of violence and sought explanations for its seemingly unforeseen eruption. By shifting the focus away from an issue that has hitherto preoccupied official narratives, the following analysis will draw attention to the more subtler ways in which identity cleansing occurred in the region. To revise our 
attention away from the conflict's brutal façade is to acknowledge the intricate nature of the Yugoslav conflict, something Western politicians and the media in particular struggled with as the crisis reached its peak. The focal point of the following study is the remaining number of self-identifying Yugoslavs, one of many nationalities of the bygone country whose gradual decline can attest to a form of 'invisible' ethnic cleansing.

The information consulted and the conclusions derived from the analysis rely on a number of sources including memoirs and interviews with a group of self-identified Yugoslavs called Naša Jugoslavija (Our Yugoslavia). ${ }^{1}$ The interviews were conducted in Slovenian and Serbo-Croatian ${ }^{2}$ and afterwards transcribed and translated into English. Due to the level of censorship regarding the Yugoslav past and the degree at which politics of memory and history enabled the erasure of Yugoslavs from the socio-political reality of everyday citizens, the collective memory approach proves impossible in the case of Yugoslavs and their personal accounts are virtually the only insight into the surviving identity available to scholars. Moreover, sample interviews can account for alternative, in this case forgotten, aspects of the social sphere and have as such invaluably contributed to this study and the exploration of the ending of Yugoslavia more generally. By using personal narratives this analysis is a critical examination of 'bottom-up' history, 'which looks not at but through events, individuals and informal organizations'(Adler, 2001, p. 277) and is therefore most suitable at reconstructing the experiences and the changes in the position of Yugoslavs amid Second Yugoslavia and now.

In the 1980 census, 1.5 million people declared themselves Yugoslav. (Drakulić, 2012, p. 129) After the war, the Yugoslav identity remained; largely dispersed around the world and its members less willing to identify themselves as such in official surveys. The continuation of their identity in the post-war period became largely overshadowed by the bloody and in places even genocidal spectacle orchestrated by extreme nationalists, which bewildered and engulfed most of the academic research thereafter. This essay will firstly examine the terminology of concepts key to the investigation, secondly, establish the context within which the cleansing occurred and finally, look at the methods through which it was achieved. These include identity declarations and anti-intellectual efforts influenced by the politics of memory: historical amnesia, confiscation of memory and alterations of the school curriculums and lastly, the detrimental terminology used by the political elites to discredit their opponents instrumental to invalidating the Yugoslav identity.

\section{......}

Naša Jugoslavija is an organisation composed of members from ex-Yugoslav republics who identify as Yugoslav not in a political (i.e. Socialist) but in a national sense. Majority belong to a generation educated in the Socialist Federal Republic of Yugoslavia, an education that according to its members imparted them with the principles of a peaceful, joint and prosperous cohabitation in the region and gave them a sense of security and dignity. The group's main goals are stabilising the relations between all Yugoslav nations and fostering reconciliation amongst its peoples by, amongst other, removing the widely endorsed misconceptions present in official narratives on Yugoslav history. ('Naša Jugoslavija', n.d.)

2 Correspondents repeatedly refered to their language as standardised Serbo-Croat, the common language of Serbs, Croats, Montenegrins and residents of Bosnia-Hercegovina as agreed in Novi Sad in 1954, rather than the individual Croatian and Serbian languages as they have existed after the break-up. (Pavkovič, 2001, p. 138) Official languages of Yugoslavia were Serbo-Croatian, Slovenian and Macedonian, although Serbian and Croatian variations were also recognized as distinct languages for legal intentions due to the subtle differences in the spelling, orthography and vocabulary between the two. (Ramet, 1992, p. 56).

One of the Naša Jugoslavija correspondents pointed at the linguistic similarity between the two languages and linked their current dissociation to the nationalist turn in the political domain of the newly formed independent states. Indeed, it is noteworthy to draw attention to one of the first cultural attempts to promote Croatian national feeling, which was concerned with the Croatian language, the 'Declaration Concerning the Name and the Position of the Croatian literary language' (Deklaracija o nazivu i položaju hrvatskog književnog jezika) signed and published by Croatian intellectuals in March 1967. The document was a renunciation of the Novi Sad agreement and in calling for full linguistic separation, the declaration prompted other forms of Serbo-Croat cooperation to be challenged as well. (Wachtel, 1998, p. 184). 
The topic of 'invisible' ethnic cleansing requires one to critically probe into the official terminology to evade confinement within the rigid boundaries produced by definitions. The following section will examine the scholarship on the subject of first ethnic cleansing, second, on group destruction and finally, on ethnicity.

In a report from May 1994 prepared by the Commission of Experts under a United Nations Security Council resolution, which affirmed instances of Genocide and Ethnic Cleansing in Bosnia and Herzegovina and Croatia, Ethnic Cleansing is defined as:

\footnotetext{
"a purposeful policy designed by one ethnic or religious group to remove by violent and terror -inspiring means the civilian population of another ethnic or religious group from certain geographic areas. To a large extent it is carried out in the name of misguided nationalism, historic grievances and a powerful driving sense of revenge." (United Nations, Security Council, 1994, p. 33)
}

Similarly, Bell-Fialkoff, an expert in the field, defined ethnic cleansing as "a planned, deliberate removal from a certain territory of an undesirable population distinguished by one or more characteristics such as ethnicity, religion, race, class or sexual preference." (Bell-Fialkoff, 1996, p. 4) According to the two interpretations, the demise in the number of Yugoslavs cannot constitute an instance of ethnic cleansing. Yugoslavs were never identified as an undesirable population by any individual Yugoslav state-their inception was never even promoted by Yugoslavia-and as such their disappearance can be considered neither planned nor deliberate. However, by shifting the focus to the subtler mechanisms of identity cleansing, we can recognise that what was deliberately planned and accomplished by the political elites of the newly independent nation states was the destruction of the Yugoslav idea upon which that identity was based. The Yugoslav idea tied the different Yugoslav nations together and became the basis for the incipient Yugoslav identity. In contrast, the nationalist discourse that developed in individual republics and was embedded within the Yugoslav conflict, denied the commonalities between the different nations and the accompanying possibility of cohabitation in one Yugoslavia based on these shared characteristics.

The forms and practices that a policy of ethnic cleansing takes on constitute crimes against humanity, defined as specified acts "committed as part of a widespread or systematic attack directed against any civilian population, with knowledge of the attack." ('International Criminal Court-What are crimes against humanity?', n.d.) The acts include murder, extermination, enslavement and rape amongst others. If proof of an intent to destroy the specified group in whole or in part is also present such acts can fall within the meaning of the 1949 Genocide Convention as well. (United Nations, Security Council, 1994, p. 26)

For the purposes of the following analysis however, interpretations of group destruction, so far examined almost exclusively from the aspect of the physical elimination, require a deeper examination. A group is a sociocultural unit. Accordingly, Martin Shaw proposes a more inclusive definition and argues, "because groups are social constructions, they can be neither constituted nor destroyed simply through the bodies of their individual members," as elimination "aims to suppress their identity by destroying the network of social relations that makes identity possible at all." In doing so it transforms the victims 
"into 'nothing' and the survivors into 'nobodies'". (Jones, 2011, p. 29) Likewise, Cathie Carmichael distinguished ethnic cleansing as "not just about murder, the wanton destruction of property, theft, rape and other violations and flight. It is about the destruction of what has been there before, an attack on memory, security and Heimat ${ }^{3}$." (Carmichael, 2002, p. 82) The 'invisible' methods of ethnic cleansing, examined in later sections, achieved precisely that-the attack on the memory of the citizens of former Yugoslavia thereby destroying the Heimat of those wishing to define themselves as Yugoslavs.

Finally, we examine the concept of ethnicity. The word 'ethnic' as defined by Fredrik Barth refers to "groups of people who are considered to have a shared identity, a common history and a traditional cultural heritage." (Barth, 1969, p. 5) However, ethnic identification is flexible in that it lacks almost any 'objective' qualities. Indeed, the 'objective' qualities are constructed upon an aggregate of 'objective' differences. The total of the differences itself does not determine the ethnicity; the latter is determined by those differences that the actors themselves regard as notable. Thus, ethnicity is above all the 'social organisation of culture difference' and not merely the empirical distinctions it promotes. (Barth, 1969, p. 6) Specific cultural attributes become promoted as symbols of the professed distinction while others completely disregarded. Groups are fluid collections of people where both similarities and differences amongst individual members are continuously present since as Michael Sandel remarked, "each of us moves in an indefinite number of communities, some more inclusive than others, each making different claims to our allegiance." (Sandel, 1982, p. 146)

The obstacle that nation-state builders in Yugoslavia had to surmount was how to classify big groups of people with hybrid identities. Prior to the development of modern nation-states, the area of former Yugoslavia was marked by interacting ethnic, lingusitic and religious influences, producing fluid and non-exclusive identities. National identities thus had to be 'invented' by exalting the chosen characteristics, habitually religion or language, and demoting the inconsistent ones. (Malakos, 1999, p. 147)

Ernst Gellner comments on the upshot of this practice, saying "[T]he members of the nation, and hence of the state, have simply forgotten their diversity of cultural origin." (Gellner, 1997, p. 45) If an ethnic group is to survive, the constructed boundary must be perpetually sustained. (Barth, 1969, p. 14) This can be related to the case of Yugoslavia, where the priority of the political elites in the Yugoslav War became the maintenance of this boundary. In doing so, the Yugoslav idea, which rejected creating boundaries between different nationalities and isolating them, was abolished. Exploring terminology is key to an 'invisible' phenomenon. Strict observance of definitions can hinder one in recognizing the subtleties of ethnic cleansing.

\section{THE ROLE OF NATIONALITIES AND THE BREAK-UP OF YUGOSLAVIA}

Before examining methods of the invisible ethnic cleansing of the Yugoslav identity, the context within which they took place must be established.

Yugoslavia first originated as the Kingdom of Serbs, Croats and Slovenes in 1918. During WWII, the Partisans led by Tito successfully assisted in liberating the region from the occupying Axis powers-Germany, Italy and the Independent state of Croatia comman-

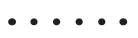

3 A German word meaning home/homeland. 
ded by the Ustaša. ${ }^{4}$ By 1945, Yugoslavia proclaimed itself a Federal Socialist Republic. (Bringa, 1995, p. 23) The republics of Yugoslavia did not exist as national territories but as federal units, home to different nations and nationalities. Based on collective and shared ambitions, the Yugoslav idea was not to replace individual national groups. (Thompson, 1992, p. 92) In order to understand the Yugoslav identity, mention of its association with the Yugoslav idea according to Yugoslavs must be made. To a respondent from Germany,

D. K., Berlin, 2015

Yugoslav identity is the sum of the common cultural history of South Slavs. [...] it does not conduct the stigmatisation and discrimination of different religious affiliations and it respects all differences as equal. [Translations were made by the author herself.]

Similarly, for a Yugoslav living in Split,

P. V., Split, 2015

[A Yugoslav identity to me signifies] a cultural, civilizational and humane move towards the future and the respect for all the values originating from the time in which Yugoslavhood was devised.

While a Yugoslav identity did emerge in Yugoslavia, the SFRY however never officially envisioned the creation of Yugoslavs. Considering intermarriage was common in Yugoslavia and reached over $10 \%$ in the 1980s, the inclusion of the Yugoslav category in official censuses, launched in 1961, seemed like a sensible solution for those children. (Wachtel, 1998, p. 240) During the 1950s, 'Yugoslav' was either assumed to be an ethnic/national category by itself or acknowledged as a supranational category. (Ramet, 1992, p. 50)

Under Tito's presidency, Yugoslav nationalities policy was comprised of eight constituents, its seventh element endorsing the idea of 'dual consciousness', allowing for both ethnic consciousness and a Yugoslav consciousness to simultaneously co-exist. This was termed 'Yugoslav socialist patriotism' and was a form of wider patriotism, which did not debar narrower patriotism, but in fact presupposed it. (Ramet, 1992, p. 54) As identity assertions were never promoted in Yugoslavia, the system operated according to a principle of 'brotherhood and unity', which sought the gradual dismantlement of class differences that would eventually lead to the creation of an equal society. (Thompson, 1992, p. 91)

In 1980 Tito's death produced a political vacuum that saw the emergence of new political elites and a catastrophic economic crisis. The Croat and Serb leadership in particular, embodied by the figures of Franjo Tuđman and Slobodan Milošević ${ }^{2}$ respectively, gradu-

\section{- • • •}

Ustaša or Insurgents were a militant independence organization that modeled itself on the Italian Fascists. To make their state more purely Croatian, the Ustaše set about exterminating its Serb, Jewish, and Roma inhabitants. They remained in control of the Independent State of Croatia until May 1945. ('Ustasa | Croatian political movement', n.d.)

5 Franjo Tuđman led Croatia to independence from Yugoslavia in 1991 after his party, Croatian Democratic Union (HDZ), won the country's first parliamentary elections in 1990. During his presidency he pushed for the creation of an ethnically homogenous Croat state and remained the president of Croatia until his death in 1999. Between 1991 and 1992, Tuđman and his HDZ right-wing allies devised a secret strategy in the Croat majority areas of Bosnia and Herzegovina by replacing moderate Croat politicians with nationalist hard-liners who began inciting violent conflicts in ethnically mixed Croat-Muslim regions of Bosnia and Herzegovina. ('Franjo Tudjman | president of Croatia', n.d.)

Slobodan Milošević (Serbia's party leader and president from 1989-1997 and President of the Federal Republic of Yugoslavia, FRY (Serbia and Montenegro) from 1997-2000) entered politics in Serbia in 1984 as Ivan Stambolić's (Head of the League of Communists of Serbia) protégé but ousted his mentor in 1987 becoming Serbia's party leader soon afterwards. Upon assuming his position, Milošević immediately transformed the language of politics in Serbia by encouraging nationalist rallies and making demands for the restoration of Serbia's control over the autonomous provinces of Vojvodina and Kosovo, which at that point enjoyed extensive autonomy granted to them by the 1974 Yugoslav Constitution under Tito. Milošević's policy staked claims to unique Serbian 'ethnic rights' and included manipulation of the extensive Serbian diaspora throughout Yugoslavia in his campaign against Yugoslav confederalism promoted by Slovenia and 
ally adopted a more nationalistic rhetoric, which appeared most successful in mobilising the populace by now highly sensitized to irreconcilable nationalist interpretations for the problems facing Yugoslavia generated by the intellectual classes within individual republics. Yugoslavia's national question thereafter developed into an assertion of mutually exclusive nationalist ideologies, which placed the internal stability of Yugoslavia at risk. (Banac, 1984, p. 413) The new rhetoric polarized the conflict and rejected the post-war political consensus Yugoslavia was constructed upon. (Magaš, 1989, p. 17) The commonalities between South Slavs professed by the previous regime were now abandoned. As nationalists function and exist through opposition, the nation-state proved to be the optimum antithesis to the multicultural Yugoslav idea. Yugoslav writer Danilo Kiš defined the nationalist as an ignoramus, who lives only by relativism, identifying himself in opposition to others. The actual content of 'the other' becomes insignificant; "The nationalist sees other people in his own image-as nationalists." (Kiš, 1991, p. 18) Reflecting the views of the author, a Yugoslav living in Ulm, Germany explained the contradiction in the attitude of a Yugoslav nationalist,

F. G., UIm, 2015

In todays post-Yugoslav countries, not only is an ethnocide being organised against my nation, but furthermore new ways of identifying national identities of former yugoslav nations are being created. Not a single national construction amongst these [ex-Yugoslav] nations passed without a Yugoslav option; on the contrary, their new national identities were attained through a reliance on the Yugoslav idea. [...]. It is precisely this feature of their national identity that is today a thorn in the side of national intellectuals. Not only do they persistently renounce and prohibit any sense of Yugoslavhood (amongst themselves), on top of that they also renounce having any affiliation to a group of Slavic nations as well.

In modern democracies nationalism often serves as a psychological instrument capable of redirecting the citizens' attention away from domestic matters-Yugoslav's economic crisis-and act as a way to gather the support for foreign policy objectives. (Habermas, 2012, p. 288) In Yugoslavia, the idea of a nation became repeatedly used not as an expression of national allegiance it allegedly stood for, but as a tool for mass mobilization. When the conflict erupted, beginning with Slovenia in June 1991 after the republic declared its independence, it became clear that the most compelling and effective way of materializing ethnic identities is through war. As Anthony Smith explained, wars "are often closely associated with the foundation and liberation myths of ethnic communities," suggesting, "that political action and military organisation have been decisive in the development of ethnic community." (Smith, 1981, p. 75) Ultimately, the 1990s Yugoslav Wars were not an inevitable conflict as it was often postulated. A respondent from Istria, Croatia, explains,

Z. S., Istria, 2015

During the war I was not too preoccupied with my national identity. I was more engaged in thinking how powerless I was in opposition to the strong, financially backed up, nationalistic

\section{-.....}

Croatia. After Slovenia, Croatia, Macedonia and Bosnia declared independence from Yugoslavia between 1991 and 1992, Milošević endorsed Serbian militias in their campaign to join the parts of Bosnia and Croatia that contained large Serbian Diasporas, with Serbia proper. He maintained his power in Serbia through a policy of mass media control and by suppressing his political adversaries while forming opportunistic alliances with others. Indeed, in March 1991 Tuđman and Milošević held a secret meeting at which they successfully devised a strategy for dividing Bosnia and Herzegovina. (Gagnon, 2004, pp. 160-161)

Milošević was finally arrested by the FRY government in 2001 following NATO's airstrike campaign against the FRY in 1999 and, once transferred to the International Criminal Tribunal for the former Yugoslavia, tried for charges of genocide, crimes against humanity and war crimes for his role in ethnic cleansing of Kosovar Albanians while president of FRY. ('Slobodan Milosevic | president of Yugoslavia', n.d.; Ramet, 2005, p. 56) 
campaign from the one side and the betrayal of the communist ideology by the leaders and members of the League of Communists in Yugoslavia from the other side. For a long time I hoped it was all just a bad dream, but with every day I became more and more convinced that this was the cruel reality which cannot bring anything good to the people.

The xenophobia, which eventually prevailed on the surface, did not arise from individual citizens.

\section{Ž. S., Banja Luka, 2015}

[...] the propaganda was frightening, even today the aggressive expressions of hostility towards one nation persist, while everyone else is presented as 'flowers' 6

In fact, the real concerns of the citizens of Yugoslavia were smothered by the deafening expressions of hostility. Dubravka Ugrešić summarized what war signified to the ordinary citizen of Yugoslavia,

The war, the dismantling of one state and the establishment of new ones, the destruction of one identity and the construction of a new one, changes in language, the end of one ideological value system and the establishment of a new one-this is the millstone which has been grinding down the citizen of former Yugoslavia for the last three years [1991-1994]. (Ugrešić, 2002f, p. 15)

The gradual destruction of the Yugoslav identity brought on by war and its socio-cultural ramifications was exacerbated by the misguided and politically imprudent influence of the West.

\section{THE ROLE OF THE WEST AND THE WESTERN MEDIA IN THE BREAK-UP}

War analysts and commentators asserted 'deep ethnic hatred' amongst individual nationalities as the root of the conflict in Second Yugoslavia. (Udovički \& Ridgeway, 1995, p. 1) Such a simplified and misrepresented assumption, labeled 'primordialist' in various analyses, absolved outside observers from making the political and intellectual effort to genuinely understand Yugoslavia's downfall.

An ethnic conflict implies that its origins lay in collective behavior; the genesis of the conflict is thus wrongly placed on the people and the extreme violence that accompanied it becomes normalized. (Wilmer, 2002, p. 67) The narrowness of statements, which drew on 'tribal' Balkan stereotypes, only reinforced the nationalistic propaganda by echoing the assertions made by ultranationalists. The latter claimed that ethnic differences within Yugoslavia could never be overcome; the western observers consolidated the claim by restricting Yugoslavia's past to one of ethnic conflict thereby completely disregarding further features of its long and intricate history. These monocausal portrayals implied 'an atemporal depoliticized image of the Balkans' while nationalism became understood as 'the quintessential feature of the Balkan condition'. (Hatzopoulos, 2003, p. 26)

Western stereotypes of the mythical Balkans continuously accompanied media reports on the evolution of the Yugoslav conflict as well. As the answer to the 'cyclical' violence of the region, nationalism-always inferred and never questioned-facilitated the

6 Pure, innocent. 
notion of Yugoslavia as a temporary and artificial construct, unsuited to the nationalistic character of its people. (Hatzopoulos, 2003, p. 36)

As Ugrešić sneeringly remarked, the dissolution of Yugoslavia signified a liberating achievement to many western commentators. It was a story of a repressed people living under the yoke of the communist regime that finally found their happy end in a new, democratic system. (Ugrešić, 2002e, p. 83) Cold War dichotomies, often entrenched in Western perceptions, influenced the opinion which perceived the conflict as a struggle between democracy and communism rather than a clash between two ultranationalist contentions. (Udovički \& Ridgeway, 1995, p. 9) Many failed to see past the veneer of purported chaos, where the main actors, engulfed in long-term power strategies, coordinated the conduct of the war with outmost rationality. (Silber \& Little, 1997, p. 27) The chaos created concealed their actions and deceived Western politicians and the outside press.

The media also served as one of the methods of invisible ethnic cleansing of the Yugoslav identity, which will be further explored later on in the analysis.

\title{
TECHNOLOGIES OF 'INVISIBLE' ETHNIC CLEANSING
}

The elimination of the Yugoslav idea from peoples' day-to-day reality was achieved through various means. Nationalism permeated the everyday reality of Yugoslav citizens and newly fabricated national concerns began to infiltrate the citizens' private sphere. The new nationalistic climate promoted identity declarations, previously considered irrelevant. In the words of a Yugoslav from Croatia,

\begin{abstract}
Z. S., Istra, 2015
I was born, raised and grew up in an environment to which nationalism was completely foreign. My father comes from Serbia and my mother from Istra with ancestors from Austria, Montenegro and Italy. My neighbours were Italian, Hungarian, Bosniak, Macedonian, Albanian... I went to school with Bulgarians, Romanians. I had very good relations with all of them. No one ever asked who are you? What are you? Where are you from? We never thought about someone's nationality. It was irrelevant to us. What was pertinent was the willingness to help one another. And that is what we did. One's personal gains were placed onto a second/ third plan. We hung out with everyone, sang their songs, celebrated their weddings, grieved at their funerals ... And again: WE WERE ALWAYS WILLING TO HELP. Therefore, I can not be exclusively a Croat, nor a Serb, nor a ... The space within these nationalistic borders is too tight-fitting for me. But I can be all of this, a Croat, and a Serb and a ...
\end{abstract}

Similarly, a respondent from Banja Luka comments on the Yugoslav identity's inclusive character, discarded by exclusive nationalist politics.

\section{Ž. S., Banja Luka, 2015}

Yugoslav identity is today mainly shaped by people that previously did not have an issue with how they defined themselves, i.e. they were well aware of their nationality, they were not terrorised into declaring themselves as such or to declare themselves as such administratively, they prided themselves in this, but they never emphasised their affiliation to impair someone else's 'identity'. From 1990 onwards, a Yugoslav 'identity' to me implies that I do not belong to a single former-Yugoslav nation. [...] Before 1990 a Yugoslav 'identity' to me signified the want to belong to all nations because I found something that shapes me as a person, enriches and motivates me in each former-Yugoslav nation, and defines me as a Yugoslav. 
People in Yugoslavia defined themselves with reference to many different and often overlapping identities. A study conducted by two Yugoslav psychologists Nikola Rot and Nenad Havelka in 1971 measured the extent of national allegiance and values among high school students in Serbia. Their research revealed the degree to which nationalist separatism was at that point insignificant amongst younger Serbs. (Wachtel, 1998, p. 192)

The majority of students were found to foster some kind of multiconstituent identity while only $20 \%$ confessed to cultivating a solely Serbian devotion. (Rot \& Havelka, 1973, p. 269) On the question of their own nationality, 64\% of students responded Serb and $32 \%$ Yugoslav; among gymnasium pupils 53\% responded Serb, $41 \%$ Yugoslav, while the rest responded with 'other'. (Rot \& Havelka, 1973, pp. 113-118)

Furthermore, the study revealed the political potential of the largest 'sway' group (students with divided attachment) who if successfully mobilized could shift their allegiance away from the medium, substituting it for a more nationalist affiliation.

For many citizens of newly formed states, the novel emphasis on one's membership in a national group signified a loss of individuality. Slavenka Drakulić recounts the loss,

in this war I am defined by my nationality, and by it alone (Drakulić, 2012, p. 56) [...] whereas before, I was defined by my education, my job, my ideas, my character-and, yes, my nationality too-now I feel stripped of all that. I am nobody because I am not a person any more. (Drakulić, 2012, p. 57)

With the Yugoslav idea rejected, self-identified Yugoslavs struggled in the war and post-war ethos. Psychologist Marja Kuzmanić's study exploring memories and identities related to the disintegration of Yugoslavia explained the practice of identity formation as a 'two-way process: of identifying and being identified'. (Kuzmanić, 2008, p. 19) The public's acceptance, nourished by those in power, is of vital importance for an identity to survive unimpeded.

A respondent from Germany recounts the lack of understanding from the public he often encountered,

F. G., UIm, 2015

[...] my national identity is for many at first irrational and non-existent, while many others do not even accept it [...]"all the constituents of my sense of nationality have in this way become practically erased and they definitely became senseless: the cultural, linguistic, economic, historical, territorial..." [...] It is like with AIDS and leprosy patients, everyone loves and sympathizes with you, but without having to have any contact with you, if possible ....

P. similarly recounts the public's reaction with regards to the divisions created by the conflict,

P., Sarajevo, 2015

I did not have any problems with who I was. The others however, did sometimes look at me weirdly. Why am I not more radical for this or the other side? They would ask me: "Why did you not identify yourself with us, we are 'yours' after all?" And then what, I stop communicating with those on the other side? I still want to be able be to interact with those 'considered different' [by nationalists]. [9]

For many, like Drakulić, the political pressure transformed her identity into "an ill-fitting shirt." (Drakulić, 2012, p. 57) What she previously cherished turned into a constraint. "That is what the war is doing to us, reducing us to one dimension: the Nation." (Drakulić, 2012, p. 57) It was not the promotion of a national identity but the rejection of an alternative, the Yugoslav one, that caused distress amongst many and which thwarted 
the self-declared Yugoslavs from being able to fully engage in and promote their identity. Upon receiving her new Croatian passport, Dubravka Ugrešić struggled to accept that everything was reduced to one dimension. She commented,

My passport has not made me a Croat. On the contrary, I am far less that today than I was before. [...] Being an ethnic 'bastard' or 'schizophrenic' is my natural choice, I even consider it a sign of mental and moral health. And I know that I am not alone. (Ugrešić, 2002b, pp. 269, 279)

For everyday people living in former Yugoslavia, a choice taken by those to continue to exist as Yugoslavs was imperceptible or impossible to understand in the frenzy created by the ultranationalist propaganda. The following passage indicates both the way in which many individuals struggled during wartime and the refuge that the Yugoslav identity offered,

\section{Z. S., Istra, 2015}

[...] after I finally realised that all of us that stood on the opposite side from the nationalists and the members of the SKJ (League of Communists in Yugoslavia), divided, abandoned and betrayed, the only ones who gave me 'refuge' were Yugoslavs. [...] before the war I did not really think about a Yugoslav nation. I simply felt like a Yugoslav. Then I realised that only them, the Yugoslavs can contest the nationalist machinery which divided the people in order to be able to govern more easily and steal from the people just the same.

The following methods of identity declarations, the media, historical amnesia, the confiscation of memory and anti-intellectual endeavors as well as new hostile aphorisms used to discredit the Yugoslav identity contributed to invisible ethnic cleansing.

\section{THE MEDIA WARS}

The Yugoslav war was a war engineered by the political elites: not by the people. In order to suppress the instincts of Yugoslav citizens the public's mentality had to be transformed in a way that would make them liable to nationalist messages. To sustain the support for extreme nationalism, a planned, persistent and strictly regulated propaganda crusade became imperative. (Udovički \& Ridgeway, 1995, p. 35) Controlled by the warmongers, the media championed the 'global conspiracy' narrative, which repudiated the Yugoslav idea. (Ahmed, 1995, p. 12) Foreign commentators, likewise deceived by the nationalistic claims, failed to recognise the extent of mutual trust present in ex-Yugoslavia.

Cooperation and trust, which tied the citizens of Yugoslavia together, were to be uprooted and replaced by confusion, mistrust and general malaise. (Milošević, 2000, p. 106) For many the inconsistency of their personal experiences and the official propaganda messages, coupled with the general insecurity at a time of war, was unnerving and to embrace the deception became a less challenging option. (Milošević, 2000, p. 122) The Yugoslav body politic gradually became paralyzed. Reduced to a depoliticized collective, their agency was at first appropriated by the ultranationalists and subsequently by the media, entrapping them within a so-called 'media gulag'. (Milošević, 2000, p. 126)

Media propaganda functioned through the method of confusion. A. S. from Canterbury, UK explained,

"As far as I can remember, it was on television that Croats first heard that they hated Serbs" (Lešić, 1995, p. 142). 
Both Milošević and Tuđman restricted the media to broadcasting authorized information only. Independent media was subject to punitive action. An independent Yugoslav TV station Yutel, dedicated to the continuation of Yugoslavia, open-mindedness and liberal ideals, was classified as treacherous. (Milošević, 2000, p. 115) Any undertaking aimed at the preservation of a multinational Yugoslav idea was suppressed. A mid-1991 survey conducted by the Institute for Political Studies in Belgrade deduced that barely $8.4 \%$ of the Serbian television viewership was knowledgeable about critical happenings in the country. A year later the survey revealed that $60 \%$ of the television audience expressed full confidence in the validity of the news while only 7\% expressed doubts. (Milošević, 2000, p. 124) In 1994 it was established that only around $3-5 \%$ of the Serb population $(300,000$ citizens) had basic access to the media and the option to participate in it. (Milošević, 1994, p. 19)

\section{HISTORICAL AMNESIA AND THE CONFISCATION OF MEMORY}

If the reader envisages the state as a house, it will be easier for him to imagine that for many inhabitants of former Yugoslavia, along with the war and the disappearance of their country, many other things have been confiscated: not only their homeland and their possessions but also their memory. In the general and obvious misery, no one takes into account invisible losses. (Ugrešić, 1996, p. 32)

The above passage written by Dubravka Ugrešić reveals the importance of memory in preserving an identity. The past can only be converted into memory if it is articulated. In post-Yugoslavia, citizens were relieved of their collective past and given a new, constructed national memory. (Ugrešić, 1996, p. 39)

With regards to the bygone past, the past which the 'new' nationalist elites shared in as well, the following observation made by historian Peter Burke seems ideal:

It is often said that history is written by the victors. It might also be said that history is forgotten by the victors [as] They can afford to forget, while the losers are unable to accept what happened and are condemned to brood over it, relive it, and reflect how different it might have been. (Burke, 1989, p. 106)

\section{POLITICS OF MEMORY: POST-YUGOSLAV MEMORY POLICY AND ITS IMPACT ON THE EDUCATION SYSTEM}

Memory and history, far from being synonymous, appear now to be in fundamental opposition. [...] [Memory] remains in permanent evolution, open to the dialectic of remembering and forgetting, unconscious of its successive deformations, vulnerable to manipulation and appropriation, susceptible to being long dormant and periodically revived. (Nora, 1989, p. 8)

The passage above, written by the French historian Pierre Nora, illustrates the malleable nature of memory. In the domain of 'collective memories', what we remember and what we forget becomes of great significance in the way that it influences collective identities. These are manufactured through myths and selected memories, as well as through a practice of 'collective amnesia'. (Jović, 2004, p. 97) 
Ernst Renan defined a nation as 'a soul [...] [constituted by] a rich legacy of memories'. (Renan, 1990, p. 19)

Under authoritarian regimes, the ruling class controls the content of 'official memories' and the struggle for power is often fought in the field of memories/forgetting. A disintegration of such a regime necessarily also involves a collapse of officially imposed memories. (Jović, 2004, p. 99) In unison, old political elites and old official memories become deposed of. In Yugoslavia, the succeeding transient period, which served to reinforce the new leadership, rapidly began to resemble the old authoritarian methods, replacing the old narrative with a new one based on new official collective memories.

Communist systems were customarily adverse to the past, interpreted in accordance with Marxist principles as 'a period of class exploitation and injustice, which ought to be replaced by a revolutionary different Future'. (Jović, 2004, p. 99) Likewise in former Yugoslavia the past was given negative and obsolete undertones. With the collapse of the regime, politically motivated official memories resuscitated the forgotten and marginalized past and in doing so, isolated those identities that were based on old memories. In Yugoslavia, the period of transition practiced the same control over official memories as did the communist regime. The chaos and the political vacuum that accompanied the disintegration created a 'blank sheet' upon which new official memories could be constructed and the newly established collective memory became a source of new collective identities. (Jović, 2004, p. 99) Through the practice of forgetting the co-existence between individual nationalities in Yugoslavia and the practice of remembering previous antagonisms, namely the animosities present during the Second World War, the new political elites sought to legitimize the conflict as historically grounded and 'self-defensive'. (Jović, 2004, p. 102) The constraint of authorities on the collective memories was such that many residents of former Yugoslavia decided to completely surrender their personal memories. In the field of politics of memory, the period of transition, which on the surface officially denied previous authoritarian practices, demonstrated a control over memories strikingly similar to the memory regulations practiced by the old regime. The transitory phase, not at all liberal as was maintained, was in fact exceedingly anti-communist and anti-Yugoslav. (Jović, 2004, p. 106)

Under Second Yugoslavia, a multiethnic and multinational federation, where ethnic differences were rarely addressed and their declarations never actively encouraged, multiple, even opposing collective memories co-existed at the same time. (Kuzmanić, 2008, p. 7) Yugoslavia was as Andrew Wachtel observed, "the quintessential battleground between collectivistic national visions based on ideals of synthesis versus those based on particularity". (Wachtel, 1998, p. 17) The shift in the political climate emphasizing those advocating the particularity of individual member states led to eventual disintegration of the regime which included a change in the 'sphere of official memories' and a 'rupture in people's private memories, representations, traditions, as well as their social and personal identities'. (Kuzmanić, 2008, p. 7)

The new political leadership erased the Yugoslav idea through anti-intellectual methods of historical amnesia and the confiscation of memory. In her newspaper articles, for which she was labeled a 'national traitor', Ugrešić continuously addressed the perils of memory manipulation, 'the terror of forgetfulness' and the oblivion of one's past.

Terror by remembering is a strategy by which the continuity (apparently interrupted) of national identity is established, terror by forgetting is the strategy whereby a 'Yugoslav' identity and any remote prospect of its being re-established is wiped out. (Ugrešić, 2002e, p. 80) 
A modern nation exists through what Ernst Rennan defined as the praxis of oblivion. (Gellner, 1997, p. 45) Correspondingly, Ugrešić writes,

The builders of the new state, the new masters of oblivion, are eliminating everything that reminds people of the old country. (...) An eye for an eye, a tooth for a tooth, the black hole of oblivion will suck us all in." (Ugrešić, 2002a, p. 109)

Politicians used pseudo-intellectual methods to rewrite the past by manipulating collective memory, which was

erased and rewritten, deconstructed, constructed and reconstructed, confiscated and reconfiscated, proclaimed politically correct or incorrect [...]. The political battle is a battle for the territory of collective memory (Ugrešić, 1996, p. 34).

\section{Furthermore,}

Ž. S., Banja Luka, 2015

Not a single former-Yugoslav country has an impartial approach to this question lof Yugoslavia] (for some it was a prison of nations, for others the prosperity of nations).

Culture became a victim of memory loss as well. An émigré from Berlin, laments the cultural deprivation, which occurred as a result of nationalistic isolation.

D. K., Berlin, 2015

Croatia's current official culture scene is for me a sterile and rigid product of the new era, robbed of its Balkan tradition, which the ruling elites that emerged during the war, aspire to distance themselves from.

Collective memory was manipulated by the reinterpretation of the past, which was revealed in education as well. Education, apart from benefitting an individual also emphasizes how one can serve the larger collective, including the national community and due to this aspect schools frequently become prone to political exploitation. (Smith, 1991, p. 118) In his discussion on the power of dominant ideologies and how they are instilled and maintained with the ordinary members of society, Louis Althusser identified two apparatuses employed by the state for this goal which take on a form of recognizable state institutions: the Repressive State Apparatus, which operates through violence and the Ideological State Apparatuses, which function 'by ideology'. (Althusser, 2001, p. 97) The first refers to organs such as the police, the military and the courts and the second to schools, the state's cultural institutions, the media, etc. When different ideologies are being contested the grasp of the Ideological State Apparatus intensifies. Correspondingly, the institution of the School communicates its 'know-how' in conformance with the ruling ideology with the intention of subjecting individuals to it or to teach them 'the mastery of its 'practice". (Althusser, 2001, p. 89) As Althusser writes, it is the overall ruling ideology which perpetuates the harmony between the Repressive and the Ideological state institutions and therefore ensures the ideology's endurance and its unconscious acceptance amongst individuals.

After the break up of SFRY, school curriculums of the newly independent states were altered in ways that complied with topical political requirements and their impact, particularly on the study of history, can be observed to this day.

Following the initial transitional period, which rejected the previously inviolable Marxist understanding of history, the past was once more subjugated to dogmatic analysis and reinterpreted along new nationalistic paradigms. Old myths were substituted by new 
ones, which drew the majority of their content from resuscitated mythology pertaining to the period of Balkan nation state formation.

In former Yugoslavia students were exposed to authors from every Yugoslav nationality.

D. K., Berlin, 2015

[...] the generations from former Yugoslavia grew up with Slovenian, Serbian, Montenegrin, Bosnian, Croat and Macedonian authors, who made up an integral part of the school curriculum, and that everyone felt and believed to be a part of their own cultural tradition. The wealth of Yugoslav diversity in every domain (not only the cultural sphere) constituted the core of Yugoslavia.

After the break up, individual national histories were fabricated through what Eric Hobsbawm described as 'retrospective mythology'. (Hobsbawm, 2012, p. 255) History, traditionally regarded as an objective informant and a source of ethnicity, now took the form of 'synchronic rhetoric', whose endeavor thereby became the appropriation of the past. (Barth, 1969, p. 6)

\section{Z. S., Istra, 2015}

It is a known fact that history is written by the winners. According to this new history that is being taught in schools, Yugoslavia is portrayed as a dictatorship, as a prison of nations... As might be expected, little is said about today's situation in this country [Croatia], and when something is said then it is bright, beautiful and everything is narrowed down to a common denominator - WE ACHIEVED INDEPENDENCE. Every discussion begins and ends here.

A respondent from Berlin similarly comments on the change in the school curriculum.

D. K., Berlin, 2015

Today's generations can only educate themselves about Yugoslavia through unofficial sources, outside of the public school curriculum. It is enough to just look at school textbooks to realise which direction education is going in, for example in Croatia. Books are (especially in the field of history) filled with pseudo science, lies and unfortunately, hatred. New history is being invented that is not related to actual historical facts whatsoever. [...] Generations are raised in isolation and in a fragmentary way, outside of any real world context.

A 2002 survey conducted by the Center for Democracy and Reconciliation in Southeast Europe entitled Clio in the Balkans uncovered the format of history education in South East Europe and the influence of political pressure onto it with a special focus on the content and the oftentimes-biased perspective introduced by schoolbooks. The study found that the shared past of separate nations, composed of general history, national history and the history of individual nations as it was taught in former Yugoslavia, had been replaced by competing ethnocentric narratives. For example, national history makes up $30 \%$ of contemporary history curriculums in Slovenia, $50 \%$ in Croatia and $70 \%$ in Serbia. (Koulouri, 2002, p. 538)

Furthermore, previously emphasised mutual understanding was replaced by historical evidence of intolerance amongst the nations of Yugoslavia to account for and reflect contemporary hostilities and moreover portray the resurgence of antagonisms as a 'revival' and the conflict as inevitable. The bulk of common Yugoslav history has been taken out of textbooks while the remnants were generally appraised in the negative. Through comparison, individual democracies recognized their treatment in the collective as unfair and produced emotive narratives of victimhood. (Koulouri, 2002, p. 39) As Stevan Pawlowitch commented, "Memory remembers what 'they' did to 'us' and forgets what 'we' did to 'them'." (Pawlowitch, 2004, p. 66) 
Regarding the Yugoslav idea, its advent in the $19^{\text {th }}$ century is covered variously: neutrally evaluated in Slovenian schoolbooks, positively in Bosnian, Macedonian, Montenegrin and Croatian (in the latter, it is depicted as the foundation of the modern Croatian state) and cautiously in Serbian sources, due to its supposed Croatian accent. (Koulouri, 2002, p. 197)

Truth is an outcome of power relations; power is utilized in the construction of truth to produce the Truth. Different truths come into conflict when one is manufactured in a way that devalues the other. (Mertus, 1999, p. 4) Post-Yugoslav states epitomized the power play engaged in truth formation, the contest particularly evident in the content of history schoolbooks, which are but a reflection of the society that produces them. A respondent from Split imparts the power of the nationalist focus on the education and therefore the mindset of entire communities,

P. V., Split, 2015

Nationalistic propaganda will continue to strive to 'brainwash' through falsifications, carry out the revision of historical truths, threaten, declare us as internal enemies and turn the methods of information and the intellectuals against us.

\section{THE NEW 'TERMINOLOGY' OF WAR}

The ambitions of most extreme nationalists are challenged when the nation-state does not succeed in converging all of its members as well as when it accepts a number of nonmembers. (Gellner, 1997, p. 4) The reluctance of Yugoslavs to adopt the newly engineered polarization of the nations made them incompatible with the nationalist agenda. Since the number of Yugoslavs - the 'non-members' -is small in comparison to other national groups, they can be discredited as what A.P. branded a "statistical error." Those who refused to consent to the political divisions, Yugoslavs included, became stigmatized as national traitors. A new idiom was invented to delegitimize Yugoslavs and other 'national traitors', Yugonostalgia. The regime in power employed the term to discredit their political opponents.

\section{Z. S., Istra, 2015}

As 'Yugonostalgia' was a term created with the intention of making even the remembrance of the name Yugoslavia negative, it leads to an aversion towards everything related to Yugoslavia.

\section{P. V., Split, 2015}

By using this concept, the nationalists openly express their fear of Yugoslavhood, express their fear of the return of those values which where specific to the Yugoslav reality, what it was known for-socialism, self-management, equality, freedom, creativity, etc.

In the new metaphorical vocabulary of former Yugoslav nations, the Yugoslav idea has come to signify a return to communism. (Ugrešić, 2002d, p.179) Legitimate claims made by the Yugoslav minority could be discredited if they were labeled as Yugonostalgic and thus connected to the bygone ideology. A respondent from Sarajevo ironically remarked,

D. K., Sarajevo, 2015

Who were the new nationalists? Old communists! 
For Yugoslavs, Yugoslavia was not a political conviction or a place permeated with ideological undertones; it was the reality into which they were born and a place they inhabited. They lived there and then. (Lešić, 1995, p. 18)

P., Sarajevo, 2015

Everyone has migrated and changed through time. We are not the same people we were twenty years ago, which means we can not be the same Yugoslavs that we were twenty years ago. In the past, Yugoslavia changed its name and its format a number of times. Each structure existed independently as it was. None was related to its predecessor. Why are we?

When the term Yugonostalgia is used as a politically distortive description for Yugoslavs, it imprisons and paralyses them in the past. Yugoslavs who are 'lost in history' can then be juxtaposed against the self-professed modern and progressive endeavors of nationalist politicians. The term Yugonostalgia functions as a method of promoting those politicians who allegedly work towards the future, and a way to discredit opposing groups who 'lost their touch with reality'. Yugonostalgia "[belongs] to the new terminology of war." (Ugrešić, 1996, p. 36)

\section{CONCLUSION}

The cleansing of Yugoslav identity was never a part of a deliberate political agenda. The conflict, however, was manipulated and orchestrated in ways that would destroy the Yugoslav idea on which the identity in question was derived from. Forced identity declarations, the hijacking of the media and various anti-intellectual efforts were the methods used to cleanse ex-Yugoslavia of the remnants of its past.

By using the concept of invisible ethnic cleansing, the following analysis draws attention to the need to give thought to and inquire into human groups who identify with state and nation projects that were in effect completely erased from the socio-political reality of their subjects by other projects of this type. Similarly to Yugoslavia, the break-up of Austro-Hungary, Czechoslovakia or the Soviet Union could have resulted in a loss of identity for those factions that identified themselves with the broader state ideals rather than the narrower category of one's ethnicity or nationality. Moreover, the analysis of Yugoslavs demonstrates the ease with which authorities can achieve an erasure of an entire group's identity through a centralized programme that exerts control over the intellectual sphere, namely education and media control.

The concept of invisible ethnic cleansing might have contemporaneous implications as well; the recent increase in the support for Scottish independence both within Scotland as well as elsewhere around the world could signify the end of Great Britain in the near future. With 10,690,999 people or $19.1 \%$ of the British population declaring themselves as 'British only' in a 2011 census examining national identity in England and Wales, a break-up of Great Britain could signify a loss of identity for those who feel an affiliation to the 'British' idea unless able to uphold it after the loss of the country. (Office for National Statistics, 2011)

In my analysis I have attempted to accomplish three tasks; to show that in Yugoslavia, despite claims suggesting its 'artificiality' and the seething 'primordial ethnic hatred', explanations which surfaced following its break-up, in the words of Andrew Wachtel 'there was in fact something to destroy'. (Wachtel, 1998, p. 227) Indeed, in his analysis 
Wachtel demonstrated the significance of the Yugoslav national idea, which he believed to be far closer to the Italian or German national idea rather than the more politically convenient forms such as those arising in the context of postcolonial Africa. (Wachtel, 1998, p. 228) The study of Yugoslavs and their commitment to the Yugoslav idea serves as a counterweight to dominant narratives, mainly the often-shortsighted Western accounts or the politicized versions of events that strive to represent the conflict and the disintegration as inevitable and the violence accompanying it as inherent.

Second, the study sought to introduce a novel concept of invisible ethnic cleansing, a frequent and unacknowledged companion of disintegrating multinational empires. By emphasizing the need for a more inclusive inquiry, a comparative history that can undermine the indoctrination with 'objective' truths, the study seeks to ensure that all losses are accounted for. "On the priority list of losses [...] the first place is the loss of life itself, then the loss of those closest, then material goods. Only then come, if they ever do, intangible losses." (Ugrešić, 1996, p. 32)

Finally, by situating the 'intangible' losses within the destruction of the Yugoslav state and citizen, this study seeks to contribute to a more comprehensive understanding of the Yugoslav conflict.

\section{BIBLIOGRAPHY}

Adler, N. (2001). In search of identity: The collapse of the Soviet Union and the recreation of Russia. In A. B. De Brito, C. G. Enriques, \& P. Aguilar (Eds.), The politics of memory and democratisation (pp. 275-302). Oxford: Oxford University Press. http://dx.doi. org/10.1093/0199240906.003.0010

Ahmed, A. S. (1995).'Ethnic cleansing': A metaphor for our time? Ethnic and Racial Studies, 18(1), 1-25. http://dx.doi.org/10.1080/01419870.1995.9993851

Althusser, L. (2001). Ideology and ideological state apparatus (Notes towards and investigation). In L. Althusser, Lenin and philosophy and other essays (pp. 85-127). New York: Monthly Review Press.

Banac, I. (1984). The national question in Yugoslavia: Origins, history, politics. Ithaca: Cornell University Press.

Barth, F. (1969). Ethnic groups and boundaries: The social organisation of culture difference. Illinois: Little, Brown and Company.

Bell-Fialkoff, A. (1996). Ethnic cleansing. New York: St. Martin's Press.

Bringa, T. (1995). Being Muslim the Bosnian way: Identity and community in a Central Bosnian village. New Jersey: Princeton University Press.

Burke, P. (1989). History as social memory. In T. Butler (Ed.), Memory: History, culture and the mind (pp. 97-113). Oxford: Blackwell.

Carmichael, C. (2002). Ethnic cleansing in the Balkans: Nationalism and the destruction of tradition. London: Routledge.

Drakulić, S. (2012). The Balkan Express: Fragments from the other side of war. Zagreb: Grafički zavod Hrvatske.

Franjo Tudjman | president of Croatia. (n.d.). In Encyclopaedia Britannica. Retrieved 31 March 20116, from http://www.britannica.com/biography/Franjo-Tudjman 
Gagnon, V. P. Jr. (2004). The myth of ethnic war: Serbia and Croatia in the 1990s. Ithaca: Cornell University Press.

Gellner, E. (1997). Nationalism. New York: New York University Press.

Habermas, J. (2012).The European nation-state: Its achievements and its limits: On the past and future of sovereignty and citizenship. In G. Balakrishnan (Ed.), Mapping the nation (pp. 281-295). London: Verso.

Hatzopoulos, P. (2003). 'All that is, is nationalist': Western imaginings of the Balkans since the Yugoslav wars. Journal of Southern Europe and the Balkans, 5(1), 25-38. http:// dx.doi.org/10.1080/1461319032000062633

Hobsbawm, E. J. (2012). Ethnicity and nationalism in Europe today. In G. Balakrishnan (Ed.), Mapping the nation (pp. 255-267). London: Verso.

International Criminal Court-What are crimes against humanity? (n.d.). Retrieved 1 April 2016, from https://www.icc-cpi.int/en_menus/icc/about\%20the\%20court/frequently\%20asked\%20questions/Pages/12.aspx

Jones, A. (2011). Genocide: A comprehensive introduction. London: Routledge.

Jović, D. (2004). 'Official memories' in post-authoritarianism: an analytical framework. Journal of Southern Europe and the Balkans, 6(2), 97-108.

Kiš, D. (1991). O Nacionalizmu: Bratska mržnja. Nedeljni List Vreme, (37), 18-19.

Koulouri, C. (Ed.). (2002). Clio in the Balkans: The politics of history education. Thessaloniki: Center for democracy and reconciliation in Southeast Europe.

Kuzmanić, M. (2008). Collective memory and social identity: A social pshychological exploration of the memories of the disintegration of former Yugoslavia. Horizons of Psychology, 17(2), 5-26.

Lešić, Z. (Ed.). (1995). Children of Atlantis: Voices from the Former Yugoslavia. Budapest: Central European University Press.

Magaš, B. (1989). Yugoslavia: The spectre of Balkanization. New Left Review, 174(1), 3-31.

Malakos, T. (1999). Globalization via ethnocratic 'ghettoization': Post-historical myths on Yugoslavia. Journal of Southern Europe and the Balkans, 1(2), 137-148. http://dx.doi. org/10.1080/14613199908413995

Mertus, J. A. (1999). Kosovo: How myths and truths started a war. Berkeley: University of California Press.

Milošević, M. (2000). The media wars: 1987-1997. In J. Udovički \& J. Ridgeway (Eds.), Burn this house: The making and unmaking of Yugoslavia (pp. 109-131). Durham: Duke University Press.

Milošević, M. (1994). Puls Treće Jugoslavije. Vreme International, 218, 19-22.

Naša Jugoslavija. (n.d.). Retrieved 30 March 2016, from http://www.nasa-jugoslavija.org/

Nora, P. (1989). Between memory and history: Les Lieux de Memoire. Representations, 26, 7-24. http://dx.doi.org/10.2307/2928520

Office for National Statistics. (2011). Census: National identity, local authorities (England and Wales) [computer file]. (This information is licensed under the terms of the Open Government License). Retrieved 5 June 2015, from http://www.ons.gov.uk/ons/publications/re-reference-tables. html? newquery $=*$ \&newoffset=0\&pageSize $=25 \&$ edition $=$ tcm\%3A77-286262

Pavković, A. (2001). Multiculturalism as a prelude to state fragmentation: The case of Yugoslavia. Journal of Southern Europe and the Balkans, 3(2), 131-143. http://dx.doi. org/10.1080/14613190120088547 
Pawlowitch, S. K. (2004). History education in the Balkans: how bad is it? Journal of Southern Europe and the Balkans, 6(1), 63-68.

Ramet, S. (1992). Nationalism and federalism in Yugoslavia, 1962-1991 (2nd ed.). Bloomington: Indiana University Press.

Ramet, S. (2005). Thinking about Yugoslavia: Scholarly debates about the Yugoslav breakup and the wars in Bosnia and Kosovo. Cambridge: Cambridge University Press. http:// dx.doi.org/10.1017/CBO9780511492136

Renan, E. (1990). What is a nation. In H. K. Bhabha (Ed.), Nation and narration (pp. 8-22). London: Routledge.

Rot, N., \& Havelka, N. (1973). Nacionalna vezanost i vrednosti kod srednješkolske omladine. Beograd: Institut za psihologiju i Institut društvenih nauka.

Sandel, M. (1982). Liberalism and the limits of justice. Cambridge: Cambridge University Press.

Silber, L., \& Little, A. (1997). Yugoslavia: Death of a nation: New York: Yale University Press.

Slobodan Milosevic | president of Yugoslavia. (n.d.). In Encyclopaedia Britannica. Retrieved 31 March 2016, from http://www.britannica.com/biography/Slobodan-Milosevic

Smith, A. D. (1981). The ethnic revival. Cambridge: Cambridge University Press.

Smith, A. D. (1991). National identity. London: University of Nevada Press.

Thompson, M. (1992). A paper house: The ending of Yugoslavia. London: Pantheon Books.

Udovički, J., \& Ridgeway, J. (Eds.). (1995). Yugoslavia's ethnic nightmare: The inside story of Europe's unfolding ordeal. New York: Lawrence Hill Books.

Ugrešić, D. (1996). Confiscation of memory. New Left Review, 1(218, July-August), 26-39.

Ugrešić, D. (2002a). Conversations, or repairing the tap in three episodes. In D. Ugrešić, The culture of lies: Antipolitical essays. Ljubljana.

Ugrešić, D. (2002b). Glossary. In D. Ugrešić, The culture of lies: Antipolitical essays. Ljubljana.

Ugrešić, D. (2002c). Kultura laži. Ljubljana.

Ugrešić, D. (2002d). Profession: Intellectual. In D. Ugrešić, The culture of lies: Antipolitical essays. Ljubljana.

Ugrešić, D. (2002e). The culture of lies. In D. Ugrešić, The culture of lies: Antipolitical essays. Ljubljana.

Ugrešić, D. (2002f). The tale of the bomb and the book. In D. Ugrešić, The culture of lies: Antipolitical essays. Ljubljana.

United Nations, Security Council. (1994). Final Report of the Commission of Experts established pursuant to Security Council Resolution 780 (1992), S/1994/674 (27 May 1994). Retrieved 23 March 2016, from http://www.icty.org/x/file/About/OTP/un_commission_of_experts_report1994_en.pdf

Ustasa | Croatian political movement. (n.d.). In Encyclopaedia Britannica. Retrieved 31 March 2016, from http://www.britannica.com/topic/Ustasa

Wachtel, A. B. (1998). Making a nation, breaking a nation: literature and culture politics in Yugoslavia. Stanford: Stanford University Press.

Wilmer, F. (2002). The social construction of man, the state and war: Identity, conflict, and violence in the former Yugoslavia. New York: Routledge. 